\title{
Impact on Psychological Capital and Adaptive Performance During Pandemic: A Study of Malaysia Young Professionals in Malaysia Service Sectors Context
}

\author{
U K Hassian, R Samuel, and S Norane
}

To Link this Article: http://dx.doi.org/10.6007/IJARBSS/v12-i1/12059

DOI:10.6007/IJARBSS/v12-i1/12059

Received: 16 November 2021, Revised: 20 December 2021, Accepted: 15 January 2022

Published Online: 29 January 2022

In-Text Citation: (Hassian et al., 2022)

To Cite this Article: Hassian, U. K., Samuel, R., \& Norane, S. (2022). Impact on Psychological Capital and Adaptive Performance During Pandemic: A Study of Malaysia Young Professionals in Malaysia Service Sectors Context. International Journal of Academic Research in Business and Social Sciences, 12(1), 16571666.

Copyright: (c) 2022 The Author(s)

Published by Human Resource Management Academic Research Society (www.hrmars.com) This article is published under the Creative Commons Attribution (CC BY 4.0) license. Anyone may reproduce, distribute, translate and create derivative works of this article (for both commercial and non0-commercial purposes), subject to full attribution to the original publication and authors. The full terms of this license may be seen at: http://creativecommons.org/licences/by/4.0/legalcode

Vol. 12, No. 1, 2022, Pg. 1657 - 1666

Full Terms \& Conditions of access and use can be found at http://hrmars.com/index.php/pages/detail/publication-ethics 


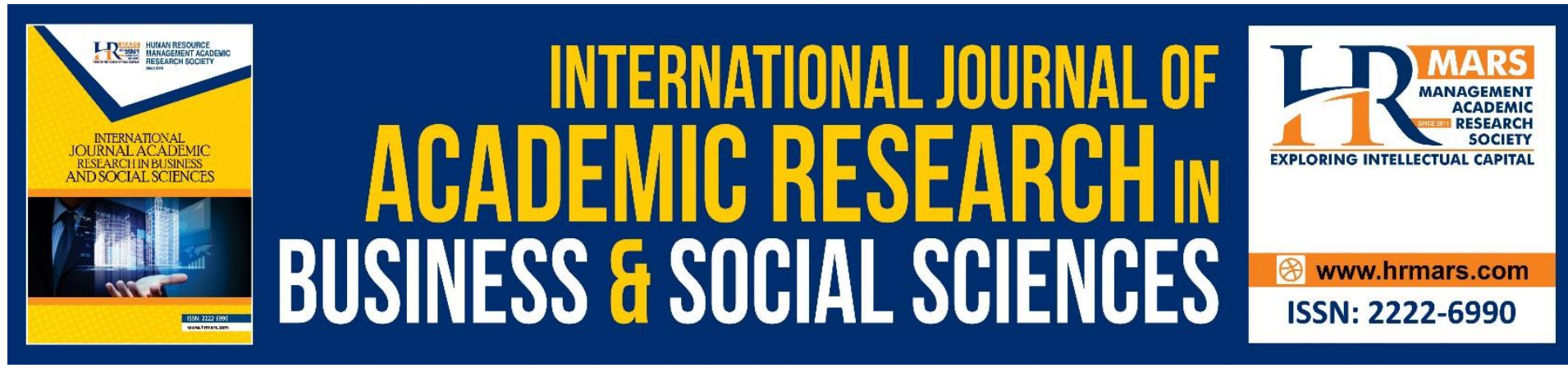

\title{
Impact on Psychological Capital and Adaptive Performance During Pandemic: A Study of Malaysia Young Professionals in Malaysia Service Sectors Context
}

\author{
U K Hassian, R Samuel, and S Noranee \\ Faculty of Business and Management, Universiti Teknologi MARA Cawangan Melaka \\ Faculty of Business and Management, UiTM Cawangan Puncak Alam
}

\begin{abstract}
Adaptive Performance Behaviour, the focus of this study, has received much attention as new workplace demands require flexible employees who are tolerant of uncertainties and can successfully perform in dynamic, competitive environments. This study examines the significance of psychological capital on adaptive performance behaviour in the context of young professionals in the Malaysian service sector. PsyCap has continually been a critical factor for optimum organization performance. This study was conducted to determine whether the same elements that impacted PsyCap were still relevant during the pandemic. With the majority of employees being requested to work from home, it is important to determine what factors still affected PsyCap. The study was conducted among young professionals in Malaysia Service Sectors. A total of 173 respondents responded to the questionnaire and data was analysed using PLS. Interestingly, hope was found statistically not a significant factor affecting adaptive performance behaviour.
\end{abstract}

\section{Introduction}

Performance is the behaviour of employees that be able to be observed in their jobs in relevance to the goals of the organization (Tyler et al., 2017). In the organizational context, performance is the most crucial concept and it could be measured through four components, namely, task, interpersonal, dedicative, and adaptive performance behaviour (Wang et al., 2018). The focus of this study is on adaptive performance behaviour as it reflects the need to clearly focus on employees' adaptability to the changes in work environment (Abukhait et al., 2019). Currently at the global level there is volatility, uncertainty, complexity and ambiguity, where technology and strategies are changing rapidly (Giones et al., 2019). At the individual stage, adaptive performance behaviour can simplify encouraging consequences such as enhanced performance capability and career success (Supriyadi et al., 2020). This would lead to organizational outcomes such as organizational learning and coping with changing customer expectations (Kasim et al., 2018).

Existing studies ((Alessandri et al., 2018; Choi et al., 2019; Tüzün et al., 2018), believes that there is a strong correlation between Psychological Capital (Psycap) and job performance of 
employees in organization. Moreover, the constant evolving of socioeconomic and technological environment highlighted the need for organizations to constantly adapt. Organizational change transforms the organization from a recent situation to another situation in the efforts to achieve greater effectiveness. PsyCap represents a positive psychological state where hope, optimism, self-efficacy, and resilience are designed to improve individual and organizational performance (Georgiou et al., 2019).

The concept of PsyCap is established to be a management concept that provides to individual achievement of high level of performance within an organization. The PsyCap concept is a product of growing interests in the studies of organizational behavior based on positive psychology (Tang et al., 2019), which consist of positive elements of hope, optimism, selfefficacy, and resilience which acts as motivational factors.

According to Pandey et al (2020), employees with high PsyCap portray high confidence and belief in their ability; hence, they will engage themselves completely into their work, which can support them to satisfy situational requirements which includes internal and external changes. Conversely, all employees have a certain level of PsyCap which helps them to perform at a certain level. In other words, higher PsyCap leads to higher performance (Anglin et al., 2018).

Adaptive performance behaviour is extremely relevant in firms where the business models and management are volatile due to technological or market evolution and environmental changes. In fact, Antilla (2019), defines the term 'organisational change' as the beginning of new work practices and technologies alongside restructuring and reorganisation arising in the workplace particularly when the world has experienced multiple changes throughout the last 50 years (Toffler, 2008). Toffler also added that majority of these changes are rooted in the industrial-based and knowledge-based economies. Along with these new changes, new challenges, and threats such as global-terrorism, strains on the financial system and threats from several pandemics (the latest being, COVID-19) exist.

\section{Literature Review}

The term "employee performance" refers to results in the sense of work achievement of exerted efforts under requisite of the job (Pradhan \& Jena, 2017). Performance evaluation is often the focus when the discussion of performance management is at play. However, the whole process of performance management develops onto more complex structures such as organizational policies, practices, and design features that are interdependently creating employees with good performance scores (Turner, 2020). Trofimova (2018), pointed out that the factors suggested by research of adaptive performance behaviour can be easily integrated as subfactors into an eight-component taxonomy, forming a hierarchical description of the latent structure of performance adaptive behaviour. Park \& Park (2019)has also stated that an important adaptive performance behaviour component for individuals adapt to new conditions or job requirements.

Adaptive Performance Behaviour for Job-Relevant Changes Due to the multi-faceted nature of the construct of performance, it has been recommended that studies address dimensions identified by (Reijseger et al., 2016) one of which is adaptive performance behaviour. Adaptive performance behaviour is a subset of 'work role performance' that revolves around preserving or enhancing performance in times of experiencing or anticipating job-relevant 
changes through reaching and revising job-relevant knowledge, skills and strategies (Carpini et al., 2017)). Yusof et al., (2018), defined adaptive performance behaviour as behaviour that describes the capability of the individual to adapt to change and transfer learning from one task to another within the change paradigm. Change is the only continual and an ever-present reality in modern organizations where adaptation is vital (Gil-Garcia et al., 2019).

Various forces within the era of globalisation have contributed to the pressure that calls for adaptive change from the organizations and their employees. The most impactful contributor to this pressure is undeniably technological change, as might be seen from the dependency upon computers in almost every current working environment. This dependence demonstrates a significant requirement of adaptive behaviour particularly from a generation growing up without the presence of computers.

Over the years, there has been a number of pandemics faced by countries throughout the globe and the most current pandemic faced on a global scale would be COVID-19 (Abodunrin \& Oloye, 2020). The on-going pandemic has forced millions to confine themselves in their homes and restrict general movement in public localities. A massive number of businesses are forced to close, and many individuals are not able to work remotely due to the natures of their jobs (Brynjolfsson et al., 2019). Advantages of Adaptive Performance Behaviour Fifteen years of research has led to unanimity with regards to the core of adaptive performance behaviour which is coping with change at all levels (individual, team and organizational). Despite the unanimity in the definition of the construct, the conceptualization and quantification (measurement methods), still remain an unresolved issue (Stasielowicz, 2019).

The amount of period spent at work has come to a point that an individual's work- life has considerably affected their personal well-being. PsyCap theory presented by Luthans has provided a pleasant perspective in analysing employees' career success (K. W. Luthans et al., 2019). In a study by Nguyen \& Ngo (2020) PsyCap was found to have an incremental impact on job satisfaction and organizational commitment in contrast to human and social capital. Psychological capital (PsyCap) is portrayed as a positive psychological state of development (Luthans et al., 2019). Conceptualised as a higher-order construct, PsyCap represents the collective variance of four constructs: hope, efficacy, resilience, and (Luthans et al., 2019).

PsyCap is more complex compared to human and social capital despite the latter being much more widely accepted and well-researched. PsyCap gains competitive advantage through progress or investment of present and future in terms of positive development (Alessandri et al., 2018). Furthermore, PsyCap provides benefits on both individual and organizational scale. On an individual scale, PsyCap could speed up growth while on an organizational scale, it could provide nourished competitive advantage, leverage, and return on investments through improved performance. The latter shows similar pattern to human and social capital (Luthans et al., 2019).

The development of service industry though changes are taking place in all sectors of the economy, the services industry has demonstrated itself to be one of the main economic builders in today's competitive and dynamic environment (Carrese, 2020). Urbanization, 
privatization and increasing demand for intermediate and final consumer service has managed to the growth of the service industry. Due to this, the services industry has evolved to be one of the main key drivers for the development of the global economy. From the Asian perspective, the advancement of the service sector of the economy is seen to be a product of digitalization and the growth of new technology. The integration between the two is deemed to be the key to the success of ASEAN from the economic standpoint. With accessibility of services and response time being the most important factors driving sales, especially in the service industry, many businesses are progressively dependent on young professionals to define best practices in service management technology and customer experience (Fisk et al., 2018). The young professionals have been deemed to be most flexible, highly professional and more IT savvy compared to professionals from other generations (Khodakarami \& Dirani, 2020).

The maturation and integration of the young professionals into the workforce has seen huge changes in how businesses operate, and the young professionals are adapting the traditional approaches and drivers of engagement to the new technological realities of the 21st century. In addition to that, the contributions of young employees are important, so vital that these young professionals will become the drivers of the industry, namely service industry, in the years to come (Bombiak \& Marciniuk-Kluska, 2019)

\section{Methodology}

This study was conducted towards young professionals within the service industry in Malaysia. For this study, researcher used $\mathrm{G} *$ Power which provides effect size calculators and graphics options. Although $\mathrm{G}$. Power estimated 85 samples for detecting a small moderation effect, a total of 300 questionnaires were distributed to 300 respondents. Only 189 responses were obtained, out of which 173 were usable.

As the sampling frame will refer the population as all the young professionals within the service industry in Malaysia, which was forecasted to reach a total of 9.3 million in 2020 (Department of Statistics, 2017). Enumerators will be appointed during the study and the questionnaires will be distributed through google form. To this study, the questionnaire is divided into 3 sections. Section A is designed to gather information on demographics and personal information. Among the items, that were included are the length of service, level of position, location. Section B contained 23 items on PsyCap. Items on the four dimensions namely, self-efficacy, hope, resilience, optimism was adapted and adopted from measurement developed by (Luthans \& Peterson, 2002). Section C consisting of 8 items measure adaptive performance and are adopted from Griffin \& Hesketh (2006). There are eight elements of adaptive performance namely handling emergencies or crisis, handling work stress, solving problem creatively, dealing with uncertain work situation, learning work tasks, technologies, and procedures, demonstrating interpersonal adaptability, demonstrating cultural adaptability, demonstrating physically oriented adaptability.

\section{Results and Discussions}

To test the validity, reliability and to hypotheses developed we used SmartPLS 3.3.3, a secondgeneration structural equation modelling software which is a robust tool to test simultaneously. 


\section{Measurement Model}

As shown in Table 1, the average variance extracted (AVE) were all above 0.5 , composite reliability (CR) was all above 0.7 thus the convergent validity and reliability of our measures were confirmed. To test the discriminant validity, we used the HTMT ratio whereby suggested that if the HTMT ratios are lower than 0.90 then there is no problem of discriminant validity. As shown in Table 2, the HTMT ratios are all lower than the 0.90 criterion as such we can conclude that our measures are distinct.

TABLE 1. Measurement Model

\begin{tabular}{|c|c|c|c|c|}
\hline $\begin{array}{l}\text { Latent } \\
\text { Variable }\end{array}$ & Item & $\begin{array}{l}\text { Outer } \\
\text { Loading }\end{array}$ & $\begin{array}{l}\text { Composite } \\
\text { Reliability }\end{array}$ & $\begin{array}{l}\text { Average variance } \\
\text { extracted }\end{array}$ \\
\hline \multirow{8}{*}{ APB } & AP1 & 0.149 & \multirow{8}{*}{0.936} & \multirow{8}{*}{0.645} \\
\hline & AP2 & 0.152 & & \\
\hline & AP3 & 0.160 & & \\
\hline & AP4 & 0.151 & & \\
\hline & AP5 & 0.148 & & \\
\hline & AP6 & 0.157 & & \\
\hline & AP7 & 0.157 & & \\
\hline & AP8 & 0.170 & & \\
\hline \multirow{6}{*}{ Self-Efficacy } & SE1 & 0.225 & \multirow{6}{*}{0.916} & \multirow{6}{*}{0.646} \\
\hline & SE2 & 0.202 & & \\
\hline & SE3 & 0.231 & & \\
\hline & SE4 & 0.201 & & \\
\hline & SE5 & 0.162 & & \\
\hline & SE6 & 0.221 & & \\
\hline \multirow{6}{*}{ Hope } & H1 & 0.209 & \multirow{6}{*}{0.915} & \multirow{6}{*}{0.643} \\
\hline & $\mathrm{H} 2$ & 0.212 & & \\
\hline & H3 & 0.194 & & \\
\hline & $\mathrm{H} 4$ & 0.181 & & \\
\hline & H5 & 0.222 & & \\
\hline & H6 & 0.227 & & \\
\hline \multirow{5}{*}{ Optimism } & 01 & 0.222 & \multirow{5}{*}{0.899} & \multirow{5}{*}{0.642} \\
\hline & 02 & 0.260 & & \\
\hline & 03 & 0.292 & & \\
\hline & 04 & 0.214 & & \\
\hline & 05 & 0.255 & & \\
\hline \multirow{6}{*}{ Resilience } & R1 & 0.213 & \multirow{6}{*}{0.901} & \multirow{6}{*}{0.604} \\
\hline & $\mathbf{R 2}$ & 0.218 & & \\
\hline & R3 & 0.192 & & \\
\hline & R4 & 0.213 & & \\
\hline & R5 & 0.226 & & \\
\hline & R6 & 0.224 & & \\
\hline
\end{tabular}


TABLE 2: Discriminant Validity (HTMT Ratio).

\begin{tabular}{lcccccc}
\hline & APB & EE & Hope & Optimism & Resilience $\begin{array}{l}\text { Self- } \\
\text { Efficacy }\end{array}$ \\
\hline APB & & & & & & \\
Hope & 0.832 & 0.827 & & & & \\
Optimism & 0.885 & 0.838 & 0.873 & & & \\
Resilience & 0.888 & 0.771 & 0.818 & 0.861 & & \\
Self-Efficacy & 0.841 & 0.703 & 0.840 & 0.748 & 0.847 & \\
\hline
\end{tabular}

TABLE 3. Hypothesis Testing

\begin{tabular}{|c|c|c|c|c|c|c|c|c|}
\hline Hypothesis & & $\begin{array}{l}\text { Std } \\
\text { Beta }\end{array}$ & $\begin{array}{l}\text { Std } \\
\text { Error }\end{array}$ & $\begin{array}{l}\mathrm{t}- \\
\text { value }\end{array}$ & $\begin{array}{l}p- \\
\text { value }\end{array}$ & $\mathrm{BCl}$ LL & $\mathrm{BCI} U \mathrm{~L}$ & f2 \\
\hline $\mathrm{H} 1$ & $\begin{array}{l}\text { Self-Efficacy -> } \\
\text { APB }\end{array}$ & 0.249 & 0.071 & 3.537 & $\begin{array}{l}p<0.0 \\
1\end{array}$ & 0.141 & 0.375 & 0.098 \\
\hline $\mathrm{H} 2$ & Hope -> APB & 0.023 & 0.073 & 0.314 & 0.377 & -0.091 & 0.145 & 0.001 \\
\hline H3 & $\begin{array}{l}\text { Resilience -> } \\
\text { APB }\end{array}$ & 0.242 & 0.074 & 3.272 & 0.001 & 0.123 & 0.368 & 0.085 \\
\hline $\mathrm{H} 4$ & $\begin{array}{l}\text { Optimism } \\
\text { APB }\end{array}$ & 0.268 & 0.064 & 4.208 & $\begin{array}{l}p<0.0 \\
1\end{array}$ & 0.166 & 0.375 & 0.097 \\
\hline
\end{tabular}

\begin{tabular}{lll}
\hline Variable & R2 & Q2 \\
\hline Adaptive Performance Behavior & 0.780 & 0.480
\end{tabular}

\section{Structural Model}

To assess the hypotheses generated we ran a bias corrected bootstrapping with a resample of 5,000 [21]. The $R^{2}=0.780\left(Q^{2}=0.480\right)$ which shows that $78.0 \%$ of the variance in Employee Engagement can be explained by the modelled variables.

To assess the hypotheses generated we ran a bias corrected bootstrapping with a resample of 5,000 showed that Self- Efficacy $(\beta=0.249 ; t=3.537 ; p<0.001)$ with Adaptive Performance Behaviour (APB), Hope $(\beta=0.022 ; t=0.314 ; p>0.001)$ with Adaptive Performance Behaviour (APB), Resilience $(\beta=0.242 ; t=3.272 ; p<0.001)$ with Adaptive Performance Behaviour (APB), and Optimism ( $\beta=0.268 ; t=4.208 ; p<0.001$ ) with Adaptive Performance Behaviour (APB) were statistically significant for $\mathrm{H} 1, \mathrm{H} 3 \mathrm{H} 4$, and for $\mathrm{H} 2$ were not supported.

\section{Future Research}

Future research would consider testing self-efficacy as mediator which might influences individuals' adaptive performance. Self-concept based motivational approach to explain the mediation of the relationship between self-efficacy and individuals' adaptive performance which could positively correlated with self-motivation. Self-motivation of followers would satisfy the psychological needs for personal motives and interpersonal connection. Study identified a variable through which self-efficacy could have an impact on adaptive performance mediate the effect of self-efficacy on performance.

\section{Conclusions}

In conclusion, it is crucial for service sector to understand and be aware of the significance of 
PsyCap, such as self-efficacy, optimism, and resilience, to enhance their adaptive performance. Hence it is relevant that both managers and employees of service sector keep themselves informed on their vision, mission, and objective to ensure the organizational will achieve their target, plan, and achieve greater business performance. This study serves as a testimony to that and stands as a reminder that the organizations should adopt innovative and creative employee engagement practices during this tough time of pandemic COVID19 to keep employees motivated, stimulated, committed, satisfied, and blissful in this tough time.

\section{Reference}

Abodunrin, O., \& Oloye, G. (2020). Coronavirus Pandemic and Its Implication on Global Economy. International Journal of Arts, Languages and Business Studies (IJALBS), 4, 1323.

Abukhait, R., Bani-Melhem, S., \& Shamsudin, F. M. (2019). DO EMPLOYEE RESILIENCE, FOCUS on OPPORTUNITY, and WORK-RELATED CURIOSITY PREDICT INNOVATIVE WORK BEHAVIOUR? The MEDIATING ROLE of CAREER ADAPTABILITY. International Journal of Innovation Management, 2050070, 1-30. https://doi.org/10.1142/S136391962050070X

Alessandri, G., Consiglio, C., Luthans, F., \& Borgogni, L. (2018). Testing a dynamic model of the impact of psychological capital on work engagement and job performance. Career Development International, 23(1), 33-47. https://doi.org/10.1108/CDI-11-2016-0210

Anglin, A. H., Short, J. C., Drover, W., Stevenson, R. M., McKenny, A. F., \& Allison, T. H. (2018). The power of positivity? The influence of positive psychological capital language on crowdfunding performance. Journal of Business Venturing, 33(4), 470-492. https://doi.org/10.1016/j.jbusvent.2018.03.003

Antilla, L. (2005). Climate of scepticism : US newspaper coverage of the science of climate change. 15(July), 338-352. https://doi.org/10.1016/j.gloenvcha.2005.08.003

Bombiak, E., \& Marciniuk-Kluska, A. (2019). Socially responsible human resource management as a concept of fostering sustainable organization-building: Experiences of young Polish companies. Sustainability (Switzerland), 11(4). https://doi.org/10.3390/su11041044

Brynjolfsson, E., Collis, A., \& Eggers, F. (2019). Using massive online choice experiments to measure changes in well-being. Proceedings of the National Academy of Sciences of the United States of America, 116(15), 7250-7255. https://doi.org/10.1073/pnas.1815663116

Carpini, J. A., Parker, S. K., \& Griffin, M. A. (2017). A look back and a leap forward: A review and synthesis of the individual work performance literature. Academy of Management Annals, 11(2), 825-885. https://doi.org/10.5465/annals.2015.0151

Carrese, L. (2020). Innovation Spaces for a Sustainable Survival.

Choi, W., Noe, R., \& Cho, Y. (2019). What is responsible for the psychological capital-job performance relationship? An examination of the role of informal learning and personenvironment fit. Journal of Managerial Psychology, 35(1), 28-41. https://doi.org/10.1108/JMP-12-2018-0562

Department of Statistics Malaysia. (2020). Vital statistics, Malaysia. [online] [Accessed 16 April 2020]https://www.dosm.gov.my/v1/index.php?r=home/index\&menu_id=b2ROaWpIT mQNnAvMHV mRjRkZzIBQT09. 
Fisk, R. P., Dean, A. M., Alkire (née Nasr), L., Joubert, A., Previte, J., Robertson, N., \& Rosenbaum, M. S. (2018). Design for service inclusion: creating inclusive service systems by 2050. Journal of Service Management, 29(5), 834-858. https://doi.org/10.1108/JOSM-05-2018-0121

Georgiou, K., Nikolaou, I., \& Turban, D. B. (2019). The Impact of a Training Intervention Developing Psychological Capital on Job Search Success. Journal of Career Development, 1-16. https://doi.org/10.1177/0894845319852425

Gil-Garcia, J. R., Guler, A., Pardo, T. A., \& Burke, G. B. (2019). Characterizing the importance of clarity of roles and responsibilities in government inter-organizational collaboration and information sharing initiatives. Government Information Quarterly, 36(4), 101393. https://doi.org/10.1016/j.giq.2019.101393

Giones, F., Brem, A., \& Berger, A. (2019). Strategic decisions in turbulent times: Lessons from the energy industry. Business Horizons, 62(2), 215-225.

https://doi.org/10.1016/j.bushor.2018.11.003

Griffin, B., \& Hesketh, B. (2006). and Career Adjustment. 55(2), 65-73.

Kasim, A., Ekinci, Y., Altinay, L., \& Hussain, K. (2018). Impact of market orientation, organizational learning and market conditions on small and medium-size hospitality enterprises. Journal of Hospitality Marketing and Management, 27(7), 855-875. https://doi.org/10.1080/19368623.2018.1438955

Khodakarami, N., \& Dirani, K. (2020). Drivers of employee engagement: differences by work area and gender. Industrial and Commercial Training, 15(1), 81-91. https://doi.org/10.1108/ICT-06-2019-0060

Luthans, F., \& Peterson, S. J. (2002). Employee engagement and manager self-efficacy: implications for managerial effectiveness and development. Journal of Management Development, 21(5), 376-387. https://doi.org/10.1108/02621710210426862

Luthans, K. W., Luthans, B. C., \& Chaffin, T. D. (2019). Refining Grit in Academic Performance: The Mediational Role of Psychological Capital. Journal of Management Education, 43(1), 35-61. https://doi.org/10.1177/1052562918804282

Nguyen, H. M., \& Ngo, T. T. (2020). Psychological capital, organizational commitment and job performance: A case in Vietnam. Journal of Asian Finance, Economics and Business, 7(5), 269-278. https://doi.org/10.13106/JAFEB.2020.VOL7.NO5.269

Pandey, J., Gupta, M., \& Hassan, Y. (2020). Intrapreneurship to engage employees: role of psychological capital. Management Decision. https://doi.org/10.1108/MD-06-20190825

Park, S., \& Park, S. (2019). Employee Adaptive Performance and Its Antecedents: Review and Synthesis. Human Resource Development Review. https://doi.org/10.1177/1534484319836315

Pradhan, R. K., \& Jena, L. K. (2017). Employee Performance at Workplace: Conceptual Model and Empirical Validation. Business Perspectives and Research, 5(1). https://doi.org/10.1177/2278533716671630

Reijseger, G., Peeters, M. C. W., Taris, T. W., Schaufeli, W. B., \& Á, I. Á. C. (2016). From Motivation to Activation: Why Engaged Workers are Better Performers. Journal of Business and Psychology. https://doi.org/10.1007/s10869-016-9435-z

Stasielowicz, L. (2019). Goal orientation and performance adaptation: A meta-analysis. Journal of Research in Personality, 82, 103847.

https://doi.org/10.1016/j.jrp.2019.103847 
Supriyadi, D., Syafitri, L. N. H., Widodo, S. F. A., Wahidi, R., Arinta, Y. N., Nabhan, F., Mufid, A., Purwanto, A., Fahlevi, M., Sunarsi, D., \& Cahyono, Y. (2020). Innovation and authentic leadership of islamic university lectures in faculty pharmacy faculty: What is the role of psychological capital? Systematic Reviews in Pharmacy, 11(8), 383-393. https://doi.org/10.31838/srp.2020.8.56

Tang, Y., Shao, Y. F., \& Chen, Y. J. (2019). Assessing the Mediation Mechanism of Job Satisfaction and Organizational Commitment on Innovative Behavior: The Perspective of Psychological Capital. Frontiers in Psychology, 10(December), 1-12. https://doi.org/10.3389/fpsyg.2019.02699

Toffler, H. (2008). Creating Adaptive Organizations Creating Adaptive Organizations : Keeping Pace with the Future. http://www.toffler.com/docs/create-adaptive-orgs-0810.pdf

Trofimova, I. (2018). Functionality versus dimensionality in psychological taxonomies, and a puzzle of emotional valence. Philosophical Transactions of the Royal Society B: Biological Sciences, 373(1744). https://doi.org/10.1098/rstb.2017.0167

Turner, P. (2020). Employee Engagement in Contemporary Organizations. In Employee Engagement in Contemporary Organizations. https://doi.org/10.1007/978-3-03036387-1

Tüzün, I. K., Çetin, F., \& Basim, H. N. (2018). Improving job performance through identification and psychological capital. International Journal of Productivity and Performance Management, 67(1), 155-170. https://doi.org/10.1108/IJPPM-03-2016-0060

Tyler, S., Wolters, H. M. K., Brien, E. O., Consortium, T., Belvoir, F., \& Dd-mm-yyyy, R. D. (2017). Using Traits as Measures for Identifying Low-Level Leadership Potential Society for Industrial and Organizational Psychology, Orlando, FL Disclaimer: All statements expressed in this paper are those of the authors and do not necessarily reflect the off. April, 1-24.

Wang, P., Lu, Z., \& Sun, J. (2018). Influential effects of intrinsic-extrinsic incentive factors on management performance in new energy enterprises. International Journal of Environmental Research and Public Health, 15(2). https://doi.org/10.3390/ijerph15020292

Yusof, M., Ani, N. A., Razak, M. A. A., \& Aziz, F. A. A. (2018). National Health and Morbidity Survey (NHMS) 2017 : Key findings from the Adolescent Health and Nutrition Surveys Infographic Booklet April 2018. National Health and Morbidity Survey (NHMS) 2017 Overview Report, April, 29. www.iku.gov.my 